\title{
Combined substrate, enzyme and yeast feed in simultaneous saccharification and fermentation allow bioethanol production from pretreated spruce biomass at high solids loadings
}

Rakesh Koppram and Lisbeth Olsson ${ }^{*}$

\begin{abstract}
Background: Economically feasible cellulosic ethanol production requires that the process can be operated at high solid loadings, which currently imparts technical challenges including inefficient mixing leading to heat and mass transfer limitations and high concentrations of inhibitory compounds hindering microbial activity during simultaneous saccharification and fermentation (SSF) process. Consequently, there is a need to develop cost effective processes overcoming the challenges when working at high solid loadings.

Results: In this study we have modified the yeast cultivation procedure and designed a SSF process to address some of the challenges at high water insoluble solids (WIS) content. The slurry of non-detoxified pretreated spruce when used in a batch SSF at 19\% (W/W) WIS was found to be inhibitory to Saccharomyces cerevisiae Thermosacc that produced $2 \mathrm{~g} \mathrm{I}^{-1}$ of ethanol. In order to reduce the inhibitory effect, the non-washed solid fraction containing reduced amount of inhibitors compared to the slurry was used in the SSF. Further, the cells were cultivated in the liquid fraction of pretreated spruce in a continuous culture wherein the outflow of cell suspension was used as cell feed to the SSF reactor in order to maintain the metabolic state of the cell. Enhanced cell viability was observed with cell, enzyme and substrate feed in a SSF producing $40 \mathrm{~g} \mathrm{I}^{-1}$ ethanol after $96 \mathrm{~h}$ corresponding to 53\% of theoretical yield based on available hexose sugars compared to $28 \mathrm{~g} \mathrm{I}^{-1}$ ethanol in SSF with enzyme and substrate feed but no cell feed resulting in 37\% of theoretical yield at a high solids loading of $20 \%$ (W/W) WIS content. The fed-batch SSF also significantly eased the mixing, which is usually challenging in batch SSF at high solids loading.

Conclusions: A simple modification of the cell cultivation procedure together with a combination of yeast, enzyme and substrate feed in a fed-batch SSF process, made it possible to operate at high solids loadings in a conventional bioreactor. The proposed process strategy significantly increased the yeast cell viability and overall ethanol yield. It was also possible to obtain $4 \%(\mathrm{w} / \mathrm{v})$ ethanol concentration, which is a minimum requirement for an economical distillation process.
\end{abstract}

Keywords: High solids, High gravity, Saccharomyces cerevisiae, SSF

\footnotetext{
*Correspondence: lisbeth.olsson@chalmers.se

Industrial Biotechnology, Department of Chemical and Biological

Engineering, Chalmers University of Technology, Göteborg SE-412 96,

Sweden
} 


\section{Introduction}

Bioethanol produced from lignocellulosic raw materials is considered as a potential transportation fuel providing long-term energy security as well as environmental and economical benefits [1]. Biological conversion of carbohydrates in lignocelluloses to ethanol can be realized by separate hydrolysis and fermentation (SHF) or simultaneous saccharification and fermentation (SSF) of the pretreated raw material. Reduced number of process reactors is one of the features of SSF, which integrates enzymatic hydrolysis and fermentation in one reactor. In SSF, the released sugars from enzymatic hydrolysis are simultaneously consumed by the fermenting microorganism, for example, Saccharomyces cerevisiae during fermentation avoiding product inhibition of enzymes and also decreasing the probability of contamination [2]. Distillation of ethanol from the fermentation broth is one of the energy intensive steps [3] and it is crucial to achieve the highest possible ethanol concentration in the fermentation broth, because the cost of distillation decreases with increase in ethanol concentration [4]. Ethanol concentration of $4 \%(\mathrm{w} / \mathrm{v})$ is the minimal requirement for an economical distillation process. By increasing the water insoluble solids (WIS) concentration in an SSF process, it is possible to achieve high sugar concentration and consequently high final ethanol concentration. Currently, when operating at a high WIS content in conventional stirred tank reactors technological challenges remain, which include high viscosity preventing efficient mixing, high power consumption [5] and high concentrations of lignocelluloses-derived inhibitors [6,7] that inhibit cellulolytic enzymes and metabolism of $S$. cerevisiae. A detailed review of the challenges encountered at high solids loading, its pervasive effect on the pretreatment, enzymatic hydrolysis and fermentation has been presented by Koppram et al. [8].

Inhomogeneity caused by inadequate mixing has been previously addressed in several ways. Different reactor designs such as a liquefaction reactor [9] and a simple rotary fermenter [10] have been designed and fabricated and the SSF functionality of these has been demonstrated using pretreated wheat straw with a dry matter content of $32 \%(\mathrm{w} / \mathrm{w})$ and higher. However, design of specialized reactors is often expensive and may restrict the functionality to a particular feedstock. Alternatively, using conventional stirred-tank reactors several groups have performed SSF in fed-batch mode with substrate and/or enzyme feed $[11,12]$ to overcome challenges when working with high WIS content. A comprehensive review of SSF has been presented by Olofsson et al. [13]. Fed-batch SSF has been shown on many occasions to be beneficial for various aspects including: (a) ease of mixing after partial saccharification, resulting in the capacity for more substrate to be added in a stepwise procedure [14]; (b) lower energy consumption due to lower viscosity [5] at any given time point compared to batch SSF; (c) low concentration of inhibitory compounds facilitating the yeast, $S$. cerevisiae to convert them to less inhibitory compounds [15], and (d) maintaining low glucose concentration in the medium, facilitating effective co-consumption of glucose and xylose by recombinant $S$. cerevisiae $[16,17]$. The potential of fed-batch SSF with substrate and enzyme feed using recombinant xylose utilizing $S$. cerevisiae, at a demo scale of a $10-\mathrm{m}^{3}$ conventional bioreactor, has also been demonstrated using 10\% $(\mathrm{w} / \mathrm{w})$ WIS content of pretreated corn cobs, producing $4 \%(\mathrm{w} / \mathrm{v})$ ethanol [18]. Although substrate and enzyme feeding strategies in SSF have been widely explored, the significance of yeast feed in an SSF process remains to be investigated. One of the elemental parts of SSF is the yeast, S. cerevisiae, which at high WIS content is subjected to high concentration of inhibitors that affect cell viability $[19,20]$, growth, ethanol yield and productivity [21-23]. Although several detoxification methods can be employed to partly remove the inhibitors [24], the cost of such methods limits their use [25]. Attempts at process modifications to curb the effects of inhibitors have been fruitful. It has been shown that prior to SSF, cultivating the cells in fed-batch mode using the liquid fraction derived from pretreatment improved tolerance towards inhibitors and ethanol productivity in an SSF process using pretreated spruce of relatively low WIS content of $8 \%(\mathrm{w} / \mathrm{w})$ [26]. However, when working at WIS content as high as $20 \%(\mathrm{w} / \mathrm{w})$, the severity of inhibition increases and therefore, maintaining the viability of yeast throughout the SSF process becomes crucial. In the present work, we developed a continuous mode of cultivation for adaptation, wherein the outflow of cell suspension from the adaptation reactor was fed to the SSF reactor with the objective of maintaining the robustness of yeast cells during the SSF process. With this mode of yeast feed together with the substrate and enzyme-cocktail feed we evaluated the performance of SSF at 20\% (w/w) WIS content using pretreated spruce as biomass. In a parallel study, a mathematical model for the SSF process has been developed and the effect of substrate, enzyme and cell feeding was analyzed (Wang R, Koppram R, Olsson L and Franzén C-J. Modeling and experimental studies of multi-feed simultaneous saccharification and co-fermentation of pretreated birch to ethanol. Manuscript).

\section{Results and discussion}

The aim of the current study was to design an SSF process of high WIS content in a conventional stirred-tank 
bioreactor. We approached this challenge by using a combination of yeast, enzyme and substrate feed as a means to improve the fermentability at high WIS. In addition, we designed a continuous process for cultivation and adaptation of the yeast stream, to allow optimum performance of the S. cerevisiae Thermosacc.

\section{Evaluation of fermentation performance of Thermosacc}

The liquid fraction of the pretreated spruce in combination with minimal medium was used in a fed-batch mode for cultivation and adaptation of Thermosacc prior to SSF and anaerobic fermentation. The slurry of pretreated spruce with $20 \%(\mathrm{w} / \mathrm{w})$ WIS content used in the batch SSF severely affected the fermentability of Thermosacc. The slurry was initially subjected to prehydrolysis for $24 \mathrm{~h}$ at $50^{\circ} \mathrm{C}$. Prehydrolysis has been shown to reduce the viscosity of the material and also improve overall ethanol yield [27]. During the prehydrolysis period of $24 \mathrm{~h}$, the slurry was sufficiently liquefied to ease mixing, which can be observed from the release of glucose (Figure 1). After $24 \mathrm{~h}$, the temperature was adjusted to $35^{\circ} \mathrm{C}$ and yeast cell suspension was added to initiate the batch SSF. However, no sugar consumption and ethanol production were observed even after $96 \mathrm{~h}$ of SSF (Figure 1).

The liquid fraction with different dilutions was also used in anaerobic fermentations to determine the optimal

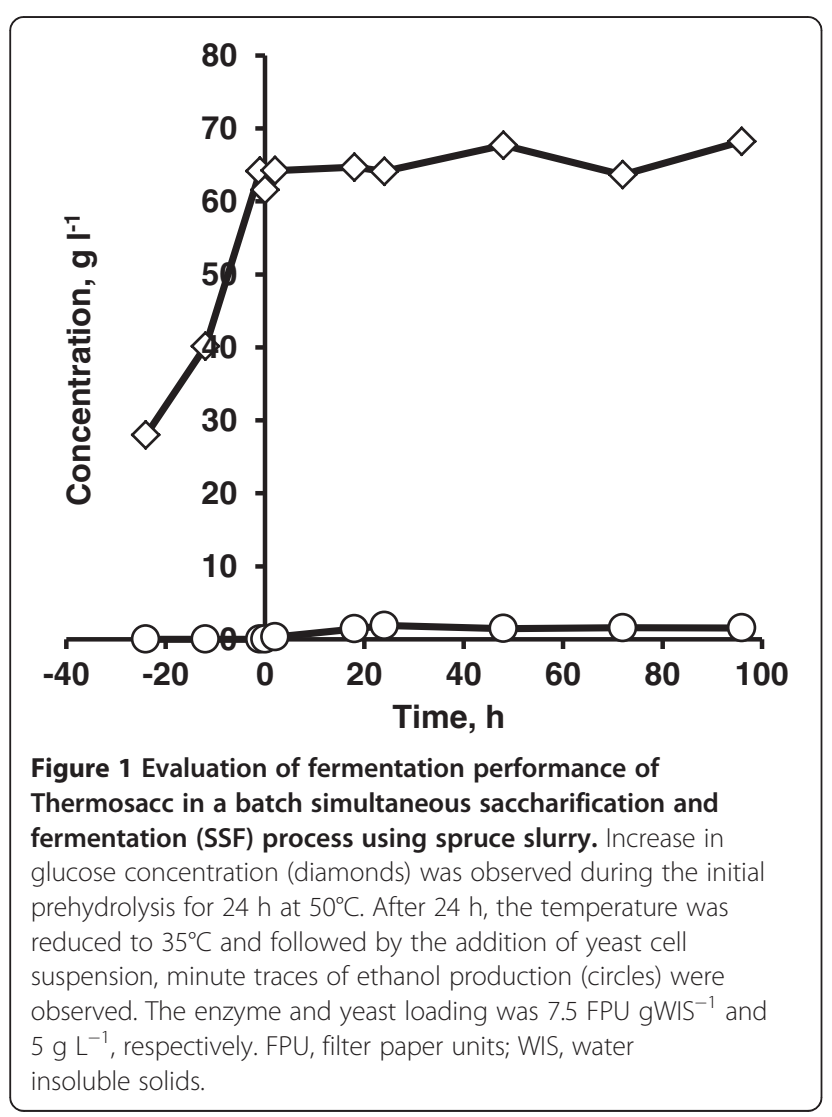

dilution that promoted fermentation. In the presence of $90 \%(\mathrm{v} / \mathrm{v})$ of liquid fraction in anaerobic fermentation no hexose sugar consumption and ethanol production were observed even after $96 \mathrm{~h}$ (Figure 2). Incidentally, when the liquid fraction was diluted to $60 \%(\mathrm{v} / \mathrm{v})$, all the glucose and mannose were consumed within $48 \mathrm{~h}$ followed by galactose in $96 \mathrm{~h}$, reaching a final ethanol concentration of $15 \mathrm{~g} \mathrm{~L}^{-1}$ (Figure 2) corresponding to $70 \%$ of the theoretical ethanol yield. Although, fed-batch adaptation of yeast using the liquid fraction did not contribute to fermentation in batch SSF of spruce slurry, reducing the inhibitors by diluting the liquid fraction in anaerobic fermentation significantly improved the fermentation performance. However, dilution contributes to increased water consumption and may not be a viable option from an industrial perspective. As most of the inhibitors are water-soluble, a significant fraction of inhibitors can be removed by separating the solid and liquid fraction. The non-washed solid fraction obtained by centrifugation of pretreated slurry contained reduced concentration of inhibitors compared to the slurry (Table 1). Also, the concentrations of inhibitors in the non-washed solid fraction were similar to the concentrations in the $60 \%(\mathrm{v} / \mathrm{v})$ liquid fraction used in the anaerobic fermentation that showed improved fermentation performance. Although the separation of pretreated slurry into liquid and solid fraction is also an energy-consuming process, it could nevertheless be essential, mainly for three reasons: (1) to use the liquid fraction to cultivate and adapt the yeast prior to SSF; (2) to

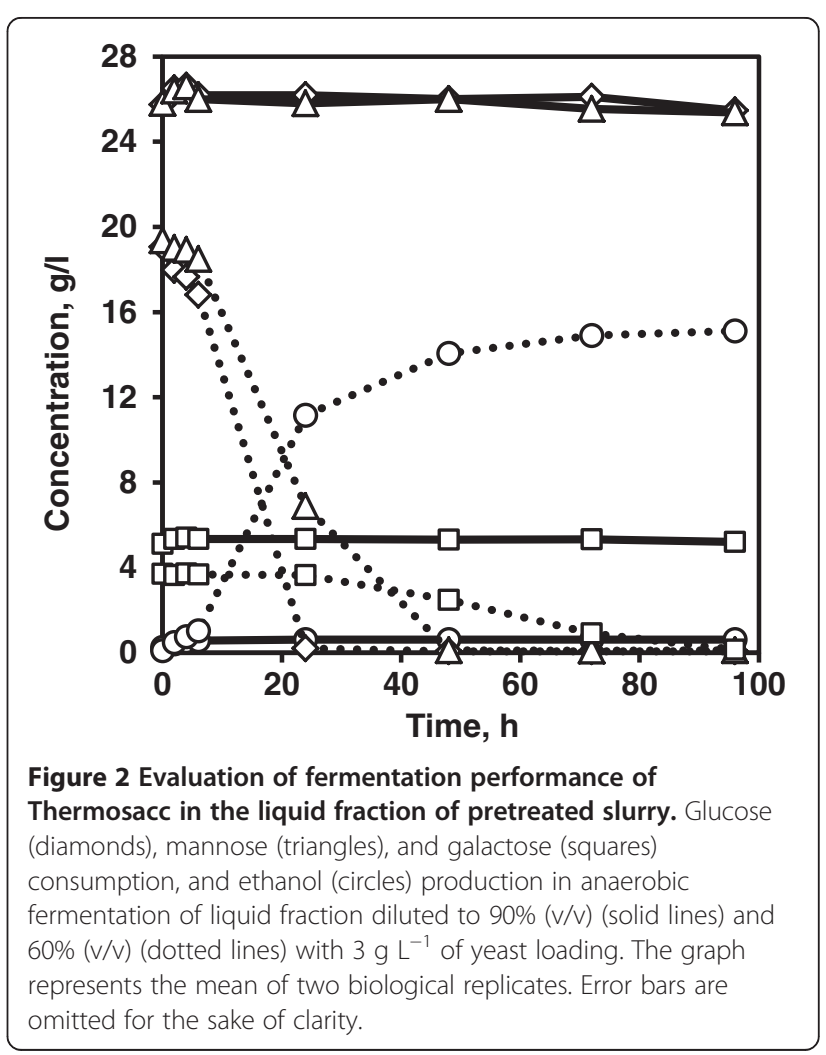


Table 1 Composition of spruce slurry and non-washed solids used in simultaneous saccharification and fermentation (SSF)

\begin{tabular}{lll}
\hline Components & $\begin{array}{l}\text { Concentration when } \\
\text { slurry was used, } \mathbf{g ~ k g}^{-\mathbf{1}^{*}}\end{array}$ & $\begin{array}{l}\text { Concentration when } \\
\text { non-washed solids } \\
\text { were used, } \mathbf{~} \mathbf{~ k g}^{-\mathbf{1}^{*}}\end{array}$ \\
\hline WIS & 200 & 200 \\
Glucan & 106 & 106 \\
Glucose & 24.8 & 14.5 \\
Mannose & 24.6 & 14.4 \\
Galactose & 4.9 & 2.9 \\
Xylose & 11.9 & 6.9 \\
HMF & 2.8 & 1.7 \\
Furfural & 2.3 & 1.3 \\
Acetic acid & 5.7 & 3.3 \\
\hline
\end{tabular}

${ }^{*}$ Concentrations correspond to a total water insoluble solids (WIS) content of $20 \%(\mathrm{w} / \mathrm{w})$ in SSF with a total working weight of $1.5 \mathrm{~kg}$. HMF,

5-hydroxy-methyl furfural.

reduce the inhibitor concentration in the solid fraction, which can then be used as substrate for SSF, and (3) to increase the WIS content in the solid fraction, which gives flexibility to operate the process with more than $20 \%$ (w/w) WIS content, which is not possible with the whole slurry obtained with the pretreatment method used in the study unless evaporation is employed.

\section{SSF with the solid fraction}

\section{High WIS content in batch SSF causes inhomogeneity}

The solid fraction obtained after centrifugation of pretreated slurry contained increased WIS content of 30\% $(\mathrm{w} / \mathrm{w})$ and reduced concentration of inhibitors (Table 1) compared to the pretreated slurry with a WIS content of $20 \%(\mathrm{w} / \mathrm{w})$. The fermentability of the solid fraction was assessed in batch SSF at 20\% (w/w) WIS content. One of the major problems encountered during the batch SSF was difficulty in mixing, and as a result, local variations in temperature $\left(35 \pm 4^{\circ} \mathrm{C}\right)$ were encountered. Sampling was unconventionally done during the batch SSF by opening the fermenter lid and manually mixing the contents with a spatula, and a small portion was then withdrawn. There was a 40-h delayed onset of glucose consumption and after $96 \mathrm{~h}$, only free glucose and mannose present in the solid fraction were consumed and the ethanol concentration reached $9.5 \mathrm{~g} \mathrm{~L}^{-1}$ (Figure 3) corresponding to $13 \%$ of the theoretical ethanol yield based on available hexose sugars. The solid fraction remained unhydrolyzed at the end of $96 \mathrm{~h}$ and no glucose was detected in the medium at this time point, which possibly indicates that the enzymes were no longer active. This can be explained by delayed stabilization of $\mathrm{pH}$ caused by difficulty in mixing, and therefore the high local $\mathrm{pH}$ possibly caused the inactivation of enzymes. Although this clearly indicates the existence of

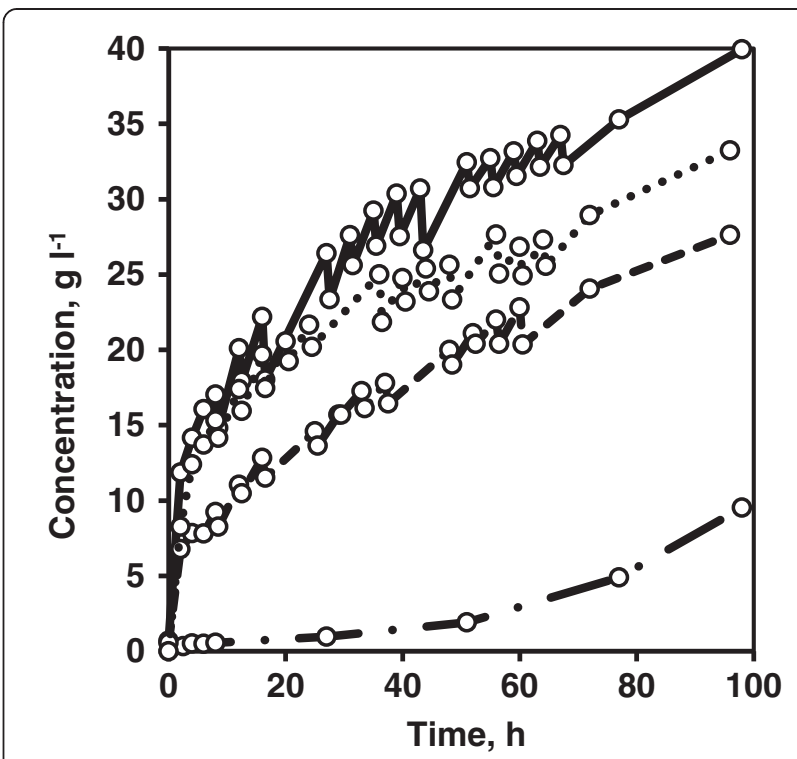

Figure 3 Comparison of ethanol production during batch and fed-batch simultaneous saccharification and fermentation (SSF) using non-washed solids as substrate. Ethanol concentration (circles) during batch SSF (dashed-dotted lines), fed-batch SSF with substrate and enzyme feed (dashed lines), fed-batch SSF with yeast and substrate feed (dotted lines) and fed-batch SSF with yeast, enzymes and substrate feed (solid lines). The graph represents the mean of two biological replicates. Error bars are omitted for the sake of clarity. The total water insoluble solids (WIS), enzyme loading and yeast loading were 20\% (w/w), 7.5 filter paper units (FPU) $\mathrm{g} \mathrm{WIS}^{-1}$ and $5 \mathrm{~g} \mathrm{~L}^{-1}$, respectively, in all the experiments.

inhomogeneity in batch SSF at high WIS content, in the next step we evaluated the possibility to use different fed-batch strategies to improve the process outcome at high WIS content.

\section{Yeast feed improves the overall ethanol yield in SSF at high} WIS content

The interplay between substrate, enzyme and yeast forms a basis for optimizing the SSF process. Several combinations to feed the substrate, enzyme preparation and yeast are possible in fed-batch SSF. Primarily, it is important to feed the substrate when working at high WIS content to improve the ethanol yield, as shown by previous studies $[28,29]$. Therefore, substrate feed remained as a minimum requirement in the current study. Together with the substrate feed the combination of enzyme and/or cell feed was also investigated (Table 2). Irrespective of the combination of feeding, the fed-batch SSF significantly improved the mixing, even though the stirrer speed was set at $400 \mathrm{rpm}$ compared to $700 \mathrm{rpm}$ in the batch SSF. This could be directly translated to lower energy-consumption for mixing, which is one of the crucial factors for an economical process. The total WIS, enzyme and yeast load in fed-batch SSF were the same as in the batch SSF. However, we initially operated the fed-batch SSF at relatively low WIS 
Table 2 Summary of simultaneous saccharification and fermentation (SSF) experiments

\begin{tabular}{|c|c|c|c|c|c|c|c|c|}
\hline \multirow{2}{*}{ SSF } & \multirow{2}{*}{ Substrate } & \multicolumn{2}{|c|}{ Water insoluble solids (WIS) } & \multirow{2}{*}{$\begin{array}{l}\text { Yeast loading } \\
\text { amount, } g\end{array}$} & \multirow{2}{*}{$\begin{array}{l}\text { Enzyme } \\
\text { loading, FPU }\end{array}$} & \multirow{2}{*}{ Glucose $e^{e}, g$} & \multicolumn{2}{|c|}{ Ethanol } \\
\hline & & $\%(w / w)$ & Amount, $\mathrm{g}$ & & & & $\mathrm{g} \mathrm{L}^{-1}$ & $\%^{f}$ \\
\hline $\mathrm{B}^{*}$ & Slurry & 19 & 285 & 7.5 & 2138 & 68.0 & 2.1 & 2 \\
\hline B & Solid fraction ${ }^{a}$ & 20 & 300 & 7.5 & 2250 & 0.1 & 9.5 & 13 \\
\hline$F B$ & Solid fraction ${ }^{a}$ & 10 to $20^{\mathrm{b}}$ & 50 to 300 & 7.5 & 1125 to $2250^{d}$ & 0.1 & 27.9 & 37 \\
\hline FB & Solid fraction ${ }^{a}$ & 10 to $20^{\mathrm{b}}$ & 50 to 300 & 3.5 to $7.5^{c}$ & 2250 & 0.5 & 33 & 44 \\
\hline FB & Solid fraction ${ }^{a}$ & 10 to $20^{\mathrm{b}}$ & 50 to 300 & 3.5 to $7.5^{c}$ & 1125 to $2250^{d}$ & 0.5 & 40 & 53 \\
\hline
\end{tabular}

*Batch SSF was carried out with prehydrolysis of $24 \mathrm{~h}$. ${ }^{\mathrm{a}}$ The solid fraction with a WIS content of $31 \%$ (w/w) was not washed and therefore, free sugars and inhibitors exist in it but in lower amounts compared to the slurry. ${ }^{\mathrm{b}}$ Fed-batch experiments started as a batch at $10 \%$ WIS with a working weight of $500 \mathrm{~g}$. After $8 \mathrm{~h}$, substrate was fed every 4 or $8 \mathrm{~h}$ until $65 \mathrm{~h}$ to a final WIS content of $20 \%$. ${ }^{\mathrm{C}}$ Fed-batch experiments started as a batch with an initial yeast loading of $3.5 \mathrm{~g}$ $\left(7 \mathrm{~g} \mathrm{~L}^{-1}\right)$. After $8 \mathrm{~h}$, cell suspension was fed every 4 or $8 \mathrm{~h}$ until $65 \mathrm{~h}$ to a final yeast amount of $7.5 \mathrm{~g}\left(5 \mathrm{~g} \mathrm{~L}^{-1}\right)$. ${ }^{\mathrm{d}}$ Fed-batch experiments started as a batch with an initial enzyme loading of 1125 filter paper units (FPU) (22.5 FPU g of WIS ${ }^{-1}$ ). After $8 \mathrm{~h}$, enzyme preparation was fed every 4 or $8 \mathrm{~h}$ until $65 \mathrm{~h}$ to a final enzyme loading of $2250 \mathrm{FPU}\left(7.5 \mathrm{FPU} \mathrm{g}\right.$ of WIS ${ }^{-1}$ ). ${ }^{\mathrm{e}}$ Residual amounts of glucose at the end of $96 \mathrm{~h}$ of SSF. ' Yield of theoretical maximum based on the total amount of glucose, mannose and galactose in the pretreated spruce. Yields are calculated for the concentrations after $96 \mathrm{~h}$ of SSF.

content and high enzyme and yeast loading per gram of WIS content. This significantly contributed to a well-mixed process. Sampling was no longer an inconvenient step because the medium was able to be drawn through the regular sampling port, which significantly decreased the contamination risk. The yeast cultivation procedure significantly affected the fermentation performance. When the cells were cultivated in fed-batch mode using the liquid fraction and added at once to the fed-batch SSF with substrate and enzyme feed, an overall ethanol yield of $37 \%$ of the theoretical maximum based on available hexose sugars was achieved. However, when the cells were cultivated in a continuous mode using the liquid fraction and fed to the SSF process with substrate feed, the overall ethanol yield was significantly increased to $44 \%$ and $53 \%$ of the theoretical maximum based on available hexose sugars with no enzyme feed and in combination with enzyme feed, respectively. The increased ethanol yield can be clearly attributed to the increased yeast viability (Figure 4) measured by counting the colonies on yeast extract peptone dextrose (YPD) plates. Higher ethanol productivity (Figure 3) and increased cell viability (Figure 4) were observed in a fed-batch SSF experiment involving feeding with continuous-mode adapted yeast compared to the fed-batch SSF experiment with fed-batch adapted yeast added all at once at the start of SSF. It can be speculated that in order to maintain the cell viability it is important to maintain the cells in a robust metabolic state, a feature that can be achieved by continuous culture as it ensures steady physicochemical conditions in the bioreactor and therefore, a physiological steady-state can theoretically be achieved [30]. It is also known that a constant product (cells) quality can be maintained in a continuous culture for a relatively longer time compared to the batch culture. Furthermore during the continuous cultivation, the concentration of inhibitors such as acetic acid, 5hydroxy-methyl furfural (HMF) and furfural were found to be near zero. This indicates that the biological conversion and detoxification of inhibitors are key aspects during the adaptation step. Therefore, adapting the cells in a fed-batch mode also to increase the cell concentration and switching the culture to a continuous mode for cell feeding in a fedbatch SSF can be advantageous from a cell viability pointof-view, especially when working at high solid loadings. Our parallel study on mathematical modeling of the process also strongly indicated increased yeast viability as an important indicator for the overall improved ethanol yield. In addition, the model also indicated increased xylose consumption when xylose-rich feedstock was employed in the multi-feed SSF process (Wang R, Koppram R, Olsson L and Franzén C-J. Modeling and experimental

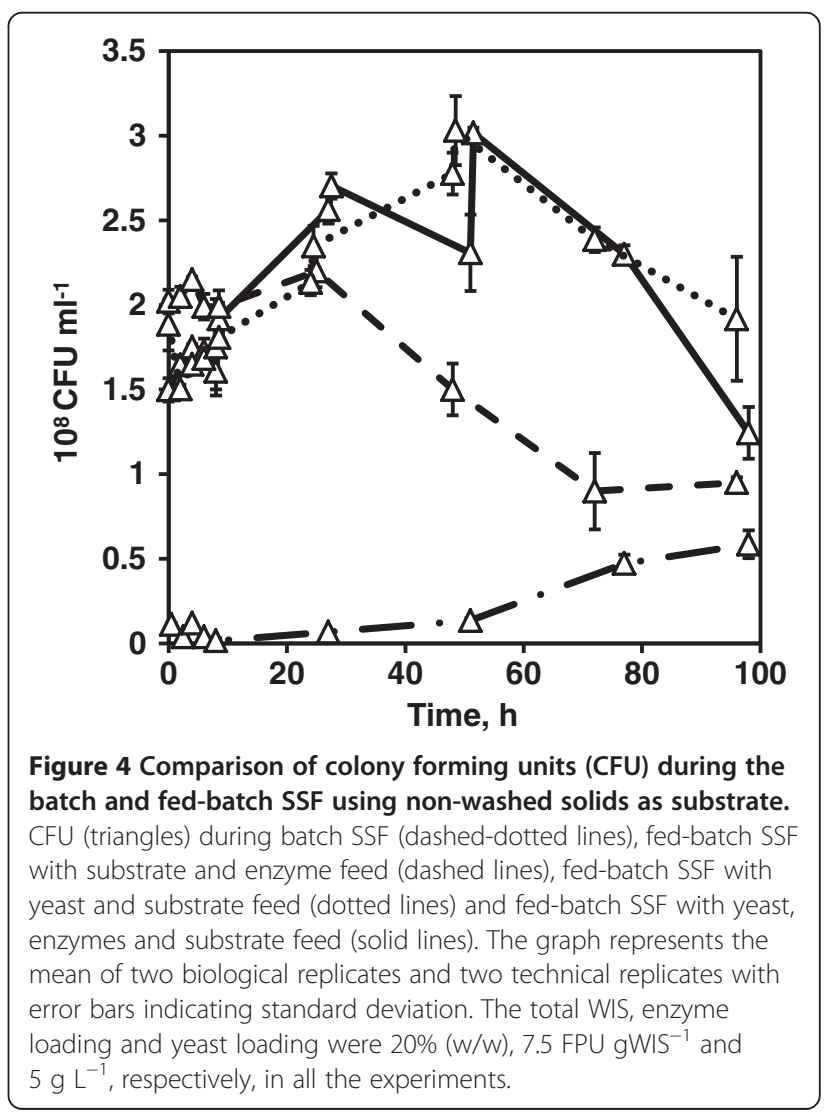


studies of multi-feed simultaneous saccharification and cofermentation of pretreated birch to ethanol. Manuscript). It has been shown that filling a $10 \mathrm{~m}^{3}$ reactor with substrate before beginning the batch SSF can be a time-consuming process [18]. However, this multi-feed SSF can be considered feasible since the process commences with the onset of substrate, enzymes and yeast feed, which can collectively reduce the overall process time. Therefore, from an industrial perspective fed-batch SSF could be an attractive feature. However, a techno-economic evaluation is needed to determine the impact of such a strategy on overall process economy, since fed-batch or a continuous mode of operation beckons good process control and associated costs.

Although the substrate feed improved the mixing and cell feed improved the cell viability, the highest observed ethanol yield was only $53 \%$ of the theoretical maximum despite the fact that a large fraction of cells remained viable even after $96 \mathrm{~h}$ of fed-batch SSF (Figure 4). The concentration levels of hexose sugars including glucose, mannose and galactose remained below $0.3 \mathrm{~g} \mathrm{~L}^{-1}$ after $96 \mathrm{~h}$, indicating that there were no fermentable monomeric sugars. This likely indicates that enzymatic hydrolysis could be a possible limiting factor affecting the overall ethanol yield. It has previously been shown that at increasing solids concentration, the proportion of adsorbed cellulase decreased because of adsorption inhibition, the mechanism of which remains elusive [31]. Also, there is previous evidence that xylose and xylooligomers with a concentration as low as $1.67 \mathrm{~g} \mathrm{~L}^{-1}$ can decrease enzymatic hydrolysis rates and yields [32]. In our study xylose was not fermentable by Thermosacc and the existence of xylose at a significant concentration of $15 \mathrm{~g} \mathrm{~L}^{-1}$ in the SSF can hinder enzymatic hydrolysis. Besides, softwoods, such as spruce, contain relatively high lignin content [13], which can cause increased nonspecific adsorption of cellulases to lignin [32] especially at high WIS content. Evidence also suggests that the simple and oligomeric phenolics generated during pretreatment, cause inhibition and precipitation of enzymes, even at low concentrations $[6,33]$. Furthermore, the operation of SSF at suboptimal temperature of enzymes combined with other aforementioned factors are some of the areas that need improvement to further increase the ethanol yields to make the process economically feasible.

\section{Conclusion}

We here demonstrated that the cultivation of yeast in a continuous culture wherein the outflow of cell suspension was fed to the SSF reactor, can significantly enhance cell viability and contribute to overall increase in ethanol yield. We also show that it is possible to work at a high WIS content of $20 \%(\mathrm{w} / \mathrm{w})$ in conventional bioreactors using a well-designed fed-batch SSF process. Furthermore, we demonstrated the production of high ethanol- concentration $\left(40 \mathrm{~g} \mathrm{~L}^{-1}\right)$, which is the minimal requirement for an economical distillation process. In addition, the potential of fed-batch SSF with substrate, enzyme and yeast feed can be improved by addressing the challenges pertaining to enzymatic hydrolysis.

\section{Methods \\ Media}

The inoculum for anaerobic fermentations and SSF experiments was prepared by cultivation in minimal medium containing $20 \mathrm{~g} \mathrm{~L}^{-1}$ glucose and enriched with salts, and 2-fold addition of vitamins and trace elements according to Verduyn et al. [34]. The $\mathrm{pH}$ of the medium was set to 6.0 with $1 \mathrm{M} \mathrm{NaOH}$ for all shake-flask cultivations. YPD plates containing $10 \mathrm{~g} \mathrm{~L}^{-1}$ yeast extract, $20 \mathrm{~g} \mathrm{~L}^{-1}$ peptone, $20 \mathrm{~g} \mathrm{~L}^{-1}$ glucose and $20 \mathrm{~g} \mathrm{~L}^{-1}$ agar were used for colony forming unit (CFU) determination during the SSF. A YNB plate containing $6.9 \mathrm{~g} \mathrm{~L}^{-1}$ yeast nitrogen base (without amino acids), $20 \mathrm{~g} \mathrm{~L}^{-1}$ glucose and $20 \mathrm{~g} \mathrm{~L}^{-1}$ agar was used to isolate individual colonies of yeast.

\section{Microorganism}

S. cerevisiae Thermosacc Dry was purchased from Lallemand, USA. The dry yeast was suspended in $5 \mathrm{ml}$ of minimal medium and a loop full of cell suspension was streaked on a YNB plate, which was later incubated at $30^{\circ} \mathrm{C}$ for 2 days. A loop full of colonies of the same size were picked and re-suspended in $50 \mathrm{ml}$ of minimal medium in a $150-\mathrm{ml}$ shake flask, which was later incubated at $30^{\circ} \mathrm{C}$ on an orbital shaker set at $180 \mathrm{rpm}$ until the late exponential phase (approximately $20 \mathrm{~h}$ ). Aliquots of cell suspension $(1 \mathrm{ml})$ were mixed with $0.5 \mathrm{ml}$ of $60 \%$ sterile glycerol and stored at $-80^{\circ} \mathrm{C}$ in sterile vials. Volumes of $100 \mu \mathrm{l}$ from the vials were used to inoculate precultures.

\section{Pretreated spruce}

Spruce slurry with a WIS content of $20.3 \%$, w/w (weight of insoluble solids to weight of slurry) was received from SEKAB-E-Technology AB (Örnsköldsvik, Sweden) and the composition of slurry is given in Table 1. The slurry was centrifuged at $10,000 \mathrm{~g}$ for 10 minutes to separate the solid and the liquid fractions. Neither the solid nor the liquid fraction was subjected to chemical or physical detoxification. The solid fraction was used as a substrate feed for SSF. The liquid fraction along with the minimal medium was used for cultivation during the adaptation step. The liquid fraction was also used for anaerobic fermentation to assess its fermentability by Thermosacc.

\section{Cultivation of Thermosacc}

The preculture for cell cultivation was developed in $50 \mathrm{ml}$ of minimal medium in a $150-\mathrm{ml}$ shake flask incubated at 
$30^{\circ} \mathrm{C}$ on an orbital shaker set at $180 \mathrm{rpm}$ for $20 \mathrm{~h}$. The cells were cultivated in a 3.6-L Infors HT-Labfors bioreactor in two stages, an initial batch phase in minimal medium, followed by a fed-batch phase of adaptation in a medium of liquid fraction with minimal medium. The batch phase was initiated by adding $50 \mathrm{ml}$ of preculture to a working volume of $500 \mathrm{ml}$, and the cultivation was carried out until the growth on glucose followed by ethanol was completed, which was indicated by $\mathrm{CO}_{2}$ evolution in the off-gas and by the dissolved oxygen concentration in the culture. Upon exhaustion of glucose and ethanol in the batch phase, a feed solution of the liquid fraction (from pretreated slurry) and minimal medium was fed linearly for $16 \mathrm{~h}$ to a final volume of $1.3 \mathrm{~L}$. The concentration of liquid fraction in the feed solution was $50 \%(\mathrm{v} / \mathrm{v})$. The minimal medium was supplemented to the feed solution to a final hexose (glucose, mannose and galactose) concentration of $50 \mathrm{~g} \mathrm{~L}^{-1}$ and the salts, vitamins and trace elements were correspondingly scaled up. The stirrer speed was set to $700 \mathrm{rpm}$ during the batch phase and increased linearly to $1,000 \mathrm{rpm}$ during the fed-batch phase. The aeration rate was maintained at 1 volume per volume per minute (vvm) and the $\mathrm{pH}$ was maintained at 5.0 by automatic addition of $2 \mathrm{M} \mathrm{NaOH}$. Cell suspension was harvested after the fed-batch phase and used as yeast loading for anaerobic fermentation and also as initial yeast loading for the subsequent fed-batch SSF process. After the fed-batch phase the cultivation process was changed to a continuous mode with the adaptation feed solution with a flow rate of $50 \mathrm{ml} \mathrm{h}^{-1}$ and the working volume was maintained at $1 \mathrm{~L}$. A part of the outflow was manually regulated as a cell suspension feed to the SSF reactor.

\section{Anaerobic fermentation in shake flasks}

The fermentation was carried out to a working volume of $50 \mathrm{ml}$ in 100-ml shake flasks fitted with a glycerol loop providing an anaerobic condition. Different concentrations of the liquid fraction $(90 \%, 60 \%$ and $40 \%(\mathrm{v} / \mathrm{v}))$ were screened. The $\mathrm{pH}$ of the liquid fraction was adjusted to 6.0 and supplemented with $0.5 \mathrm{~g} \mathrm{l}^{-1}\left(\mathrm{NH}_{4}\right)_{2} \mathrm{HPO}_{4}, 125 \mathrm{ppm}$ of vitahop (Betatech Gmbh, Schwabach, Germany) (to suppress bacterial growth). The fermentation was initiated by adding harvested cell suspension to reach a yeast concentration of $3 \mathrm{~g}$ dry weight $\mathrm{L}^{-1}$. The flasks were incubated at $30^{\circ} \mathrm{C}$ on an orbital shaker set at $180 \mathrm{rpm}$ for $96 \mathrm{~h}$ and samples were withdrawn for optical density $(\mathrm{OD})_{650}$ measurement and extracellular metabolite analysis.

\section{SSF}

All the SSF experiments were carried out to a total WIS content of $20 \%(\mathrm{w} / \mathrm{w})$, total enzyme loading of $7.5 \mathrm{FPU} \mathrm{g}^{-1}$ WIS, total yeast loading of $5 \mathrm{~g}$ dry weight $\mathrm{L}^{-1}$ and to a final working weight of $1.5 \mathrm{~kg}$ in 3.6-L Infors HT-Labfors reactors. An enzyme preparation, Cellic Ctec-2 from
Novozymes A/S, Denmark with a filter paper activity of $149 \mathrm{FPU} \mathrm{g}^{-1}$ enzyme, $\beta$-glucosidase activity of $590 \mathrm{IU} \mathrm{g}^{-1}$ enzyme was used. The solid fraction of the pretreated spruce was used as the substrate, and the $\mathrm{pH}$ of this was adjusted to 5.0 using $10 \mathrm{M} \mathrm{NaOH}$ and supplemented with $0.5 \mathrm{~g} \mathrm{~L}^{-1}\left(\mathrm{NH}_{4}\right)_{2} \mathrm{HPO}_{4}$ and $125 \mathrm{ppm}$ of vitahop. Batch SSF was initiated by adding fed-batch adapted cell suspension and enzyme preparation. Fed-batch SSF was initially started as a batch SSF of $500 \mathrm{~g}$ as a working weight with $10 \%(\mathrm{w} /$ w) WIS content, $50 \%$ of total yeast cell suspension (fedbatch adapted) and 50\% of total enzyme preparation. After an initial period of $8 \mathrm{~h}$ of batch SSF the solid fraction, enzyme preparation and yeast cell suspension (continuous mode adapted) were manually fed every 4 or $8 \mathrm{~h}$. The manual feeding was carried out for a period of $65 \mathrm{~h}$. Fed-batch SSF with substrate and enzyme-cocktail feed was carried out in a similar way but with all the required yeast cell suspension added at the beginning. Fed-batch SSF with substrate and cell-suspension feed was carried out in a similar manner but with all the required enzyme preparation added at the beginning. The temperature was maintained at $35^{\circ} \mathrm{C}$ and $\mathrm{pH}$ at 5.0 by automatic addition of $5 \mathrm{M} \mathrm{NaOH}$. The stirrer speed was set at $700 \mathrm{rpm}$ for batch SSF and $400 \mathrm{rpm}$ for fed-batch SSF. All the experiments were carried out in duplicates.

\section{Colony-forming units}

Samples collected during the SSF were serially diluted using sterile normal saline solution; $100 \mu \mathrm{l}$ of two of the dilutions were plated on YPD plates and incubated at $30^{\circ} \mathrm{C}$ for 2 days and the colonies were counted and represented as CFU $\mathrm{ml}^{-1}$.

\section{Sample preparation}

To make the sample pipettable equivalent to water, $1 \mathrm{~g}$ of the withdrawn sample from SSF was diluted five times with milliQ water. The diluted samples were quantified for metabolites by HPLC. The concentrations (including the dilution factor) of metabolites obtained by HPLC were represented in $\mathrm{g}$ (metabolite) $\mathrm{kg}$ (slurry) ${ }^{-1}$. This concentration was used to determine the yields presented in Table 2. However, for the data representation in the graphs and elsewhere in the text, the concentration $\left(\mathrm{g} \mathrm{kg}^{-1}\right)$ was converted to concentration $\left(\mathrm{g} \mathrm{L}^{-1}\right)$ by multiplying with a conversion factor of $1.06\left(\mathrm{~kg} \mathrm{~L}^{-1}\right)$. The conversion factor was determined by pipetting $1 \mathrm{ml}$ of slurry using a cut tip and weighing.

\section{Analysis of metabolites}

Samples for extracellular metabolites were analyzed by HPLC using Aminex HPX-87H column with $30 \times$ $4.6 \mathrm{~mm}$ Cation-H Biorad micro-guard column (Bio-Rad Laboratories $\mathrm{AB}$, Solna, Sweden) maintained at $45^{\circ} \mathrm{C}$; $5 \mathrm{mM} \mathrm{H}_{2} \mathrm{SO}_{4}$ was used as an eluent at a flow rate of 
$0.6 \mathrm{ml} \mathrm{min}^{-1}$. Glycerol, ethanol and acetic acid were detected using an RI detector maintained at $35^{\circ} \mathrm{C}$; HMF and furfural were detected using a UV detector at $210 \mathrm{~nm}$. The monomeric sugars in the samples were analyzed by high performance anion exchange chromatography using $4 \times 250 \mathrm{~mm}$ Dionex CarboPac PA1 column with $4 \times 50 \mathrm{~mm}$ guard column (Thermo Scientific, Sweden) maintained at $30^{\circ} \mathrm{C}$. Eluent A: $300 \mathrm{mM} \mathrm{NaOH}$, eluent B: $100 \mathrm{mM} \mathrm{NaOH}+85 \mathrm{mM}$ sodium acetate were used for elution at a flow rate of $1 \mathrm{ml} \mathrm{min}^{-1}$. Monosaccharides including galactose, glucose and mannose were detected using pulsed amperometric detector.

\section{Ethanol yield calculation}

The ethanol yield was represented as \% of the maximum theoretical yield based on total available hexose sugars. The sum of available fermentable sugars, including glucose, mannose and galactose in the liquid fraction and WIS fraction was calculated. Due to the addition of water during hydrolysis, the theoretical weight of glucose released is 1.11 times the weight of glucan. By using the maximum theoretical ethanol yield of $0.51 \mathrm{~g} \mathrm{~g}^{-1}$ sugar, the maximum ethanol that can be produced from total available sugars was calculated. The percentage of the theoretical ethanol yield is defined as:

$$
\begin{aligned}
& \mathrm{Y}_{\mathrm{SE}}=100^{*} \text { produced amount of ethanol }(\mathrm{g}) / \\
& \text { maximum theoretical amount of ethanol }(\mathrm{g})
\end{aligned}
$$

\footnotetext{
Abbreviations

CFU: colony-forming units; FPU: filter paper units; HMF: 5-hydroxy-methyl furfural; HPAEC: high performance anion exchange chromatography; HPLC: high performance liquid chromatography; SSF: simultaneous saccharification and fermentation; WIS: water insoluble solids; YPD: yeast extract peptone dextrose.
}

\section{Competing interests}

The authors declare no conflicts of interest.

\section{Authors' contributions}

RK and LO were involved in the conception and design of the study. RK performed the experimental work. RK and LO critically analyzed the data. RK wrote the manuscript. Both authors commented on the manuscript, and read and approved the final manuscript.

\section{Acknowledgements \\ This work was a part of the project 'High Gravity Biofuels' funded by Top level Nordic Research Institute. We thank SEKAB-E-Technology AB for providing us with pretreated spruce. The authors thank Associate Professor Carl Johan Franzén, Dr Charilaos Xiros and Ruifei Wang for the valuable discussion.}

Received: 24 December 2013 Accepted: 13 March 2014 Published: 8 April 2014

\section{References}

1. Balat M: Production of bioethanol from lignocellulosic materials via the biochemical pathway: a review. Energ Convers Manage 2011, 52:858-875.

2. Galbe M, Zacchi G: A review of the production of ethanol from softwood. Appl Microbiol Biotechnol 2002, 59:618-628.
3. Wingren A, Galbe M, Zacchi G: Techno-economic evaluation of producing ethanol from softwood: comparison of SSF and SHF and identification of bottlenecks. Biotechnol Prog 2003, 19:1109-1117.

4. Zacchi G, Axelsson A: Economic-evaluation of preconcentration in production of ethanol from dilute sugar solutions. Biotechnol Bioeng 1989, 34:223-233.

5. Dasari RK, Dunaway K, Berson RE: A scraped surface bioreactor for enzymatic saccharification of pretreated corn stover slurries. Energ Fuel 2009, 23:492-497.

6. Kim Y, Ximenes E, Mosier NS, Ladisch MR: Soluble inhibitors/deactivators of cellulase enzymes from lignocellulosic biomass. Enzym Microb Technol 2011, 48:408-415.

7. Almeida JRM, Modig T, Petersson A, Hahn-Hägerdal B, Liden G, Gorwa-Grauslund MF: Increased tolerance and conversion of inhibitors in lignocellulosic hydrolysates by Saccharomyces cerevisiae. I Chem Technol Biotechnol 2007, 82:340-349.

8. Koppram R, Tomas-Pejo E, Xiros C, Olsson L: Lignocellulosic ethanol production at high-gravity: challenges and perspectives. Trends Biotechnol 2014, 32:46-53.

9. Jorgensen H, Vibe-Pedersen J, Larsen J, Felby C: Liquefaction of lignocellulose at high-solids concentrations. Biotechnol Bioeng 2007, 96:862-870.

10. Mohagheghi A, Tucker M, Grohmann K, Wyman C: High solids simultaneous Saccharification and fermentation of pretreated wheat straw to ethanol. Appl Biochem Biotechnol 1992, 33:67-81.

11. Zhang MJ, Wang F, Su RX, Qi W, He ZM: Ethanol production from high dry matter corncob using fed-batch simultaneous saccharification and fermentation after combined pretreatment. Bioresour Technol 2010, 101:4959-4964.

12. Hoyer K, Galbe M, Zacchi G: Effects of enzyme feeding strategy on ethanol yield in fed-batch simultaneous saccharification and fermentation of spruce at high dry matter. Biotechnol Biofuels 2010, 3:14.

13. Olofsson K, Bertilsson M, Liden G: A short review on SSF - an interesting process option for ethanol production from lignocellulosic feedstocks. Biotechnol Biofuels 2008, 1:7.

14. Rudolf A, Alkasrawi M, Zacchi G, Liden G: A comparison between batch and fed-batch simultaneous saccharification and fermentation of steam pretreated spruce. Enzym Microb Technol 2005, 37:195-204.

15. Taherzadeh MJ, Niklasson C, Lidén G: Conversion of dilute-acid hydrolyzates of spruce and birch to ethanol by fed-batch fermentation. Bioresour Technol 1999, 69:59-66.

16. Öhgren K, Bengtsson O, Gorwa-Grauslund MF, Galbe M, Hahn-Hägerdal B, Zacchi G: Simultaneous saccharification and co-fermentation of glucose and xylose in steam-pretreated corn stover at high fiber content with Saccharomyces cerevisiae TMB3400. J Biotechnol 2006, 126:488-498,

17. Olofsson K, Rudolf A, Lidén G: Designing simultaneous saccharification and fermentation for improved xylose conversion by a recombinant strain of Saccharomyces cerevisiae. J Biotechnol 2008, 134:112-120.

18. Koppram R, Nielsen F, Albers E, Lambert A, Wannström S, Welin L, Zacchi G, Olsson L: Simultaneous saccharification and co-fermentation for bioethanol production using corncobs at lab, PDU and demo scales. Biotechnol Biofuels 2013, 6:2.

19. Lin FM, Qiao B, Yuan YJ: Comparative proteomic analysis of tolerance and adaptation of ethanologenic Saccharomyces cerevisiae to furfural, a lignocellulosic inhibitory compound. Appl Environ Microbiol 2009, 75:3765-3776.

20. Pinel D, D'Aoust F, del Cardayre SB, Bajwa PK, Lee H, Martin VJJ: Saccharomyces cerevisiae genome shuffling through recursive population mating leads to improved tolerance to spent sulfite liquor. Appl Environ Microbiol 2011, 77:4736-4743.

21. Palmqvist E, Grage H, Meinander NQ, Hahn-Hägerdal B: Main and interaction effects of acetic acid, furfural, and p-hydroxybenzoic acid on growth and ethanol productivity of yeasts. Biotechnol Bioeng 1999, 63:46-55.

22. Larsson S, Quintana-Sainz A, Reimann A, Nilvebrant NO, Jönsson LJ: Influence of lignocellulose-derived aromatic compounds on oxygenlimited growth and ethanolic fermentation by Saccharomyces cerevisiae. Appl Biochem Biotechnol 2000, 84-6:617-632.

23. Koppram R, Albers E, Olsson L: Evolutionary engineering strategies to enhance tolerance of xylose utilizing recombinant yeast to inhibitors derived from spruce biomass. Biotechnol Biofuels 2012, 5:32.

24. Larsson S, Reimann A, Nilvebrant NO, Jönsson LJ: Comparison of different methods for the detoxification of lignocellulose hydrolyzates of spruce. Appl Biochem Biotechnol 1999, 77-9:91-103. 
25. Vonsivers M, Zacchi G, Olsson L, Hahn-Hägerdal B: Cost-analysis of ethanolproduction from willow using recombinant Escherichia coli. Biotechnol Prog 1994, 10:555-560

26. Alkasrawi M, Rudolf A, Liden G, Zacchi G: Influence of strain and cultivation procedure on the performance of simultaneous saccharification and fermentation of steam pretreated spruce. Enzym Microb Technol 2006, 38:279-286.

27. Hoyer K, Galbe M, Zacchi G: The effect of prehydrolysis and improved mixing on high-solids batch simultaneous saccharification and fermentation of spruce to ethanol. Process Biochem 2013, 48:289-293.

28. Hoyer K, Galbe M, Zacchi G: Production of fuel ethanol from softwood by simultaneous saccharification and fermentation at high dry matter content. J Chem Technol Biotechnol 2009, 84:570-577.

29. Liu K, Lin XH, Yue J, Li XZ, Fang X, Zhu MT, Lin JQ, Qu YB, Xiao L: High concentration ethanol production from corncob residues by fed-batch strategy. Bioresour Technol 2010, 101:4952-4958.

30. Daran-Lapujade P, Daran JM, van Maris AJA, de Winde JH, Pronk JT: Chemostat-based micro-array analysis in Baker's yeast. Adv Microb Physiol 2009, 54:257-311.

31. Kristensen JB, Felby C, Jorgensen H: Yield-determining factors in high-solids enzymatic hydrolysis of lignocellulose. Biotechnol Biofuels 2009, 2:11.

32. Qing Q, Yang B, Wyman CE: Xylooligomers are strong inhibitors of cellulose hydrolysis by enzymes. Bioresour Technol 2010, 101:9624-9630.

33. Tejirian A, Xu F: Inhibition of enzymatic cellulolysis by phenolic compounds. Enzym Microb Technol 2011, 48:239-247.

34. Verduyn C, Postma E, Scheffers WA, Vandijken JP: Effect of benzoic-acid on metabolic fluxes in yeasts - a continuous-culture study on the regulation of respiration and alcoholic fermentation. Yeast 1992, 8:501-517.

doi:10.1186/1754-6834-7-54

Cite this article as: Koppram and Olsson: Combined substrate, enzyme and yeast feed in simultaneous saccharification and fermentation allow bioethanol production from pretreated spruce biomass at high solids loadings. Biotechnology for Biofuels 2014 7:54.

\section{Submit your next manuscript to BioMed Central and take full advantage of:}

- Convenient online submission

- Thorough peer review

- No space constraints or color figure charges

- Immediate publication on acceptance

- Inclusion in PubMed, CAS, Scopus and Google Scholar

- Research which is freely available for redistribution 